\title{
Menemukan Tuhan dalam Segalanya: Analisis Spiritualitas Kristiani dalam Puisi
}

\author{
Novita Dewi \\ Universitas Sanata Dharma \\ novitadewi@usd.ac.id
}

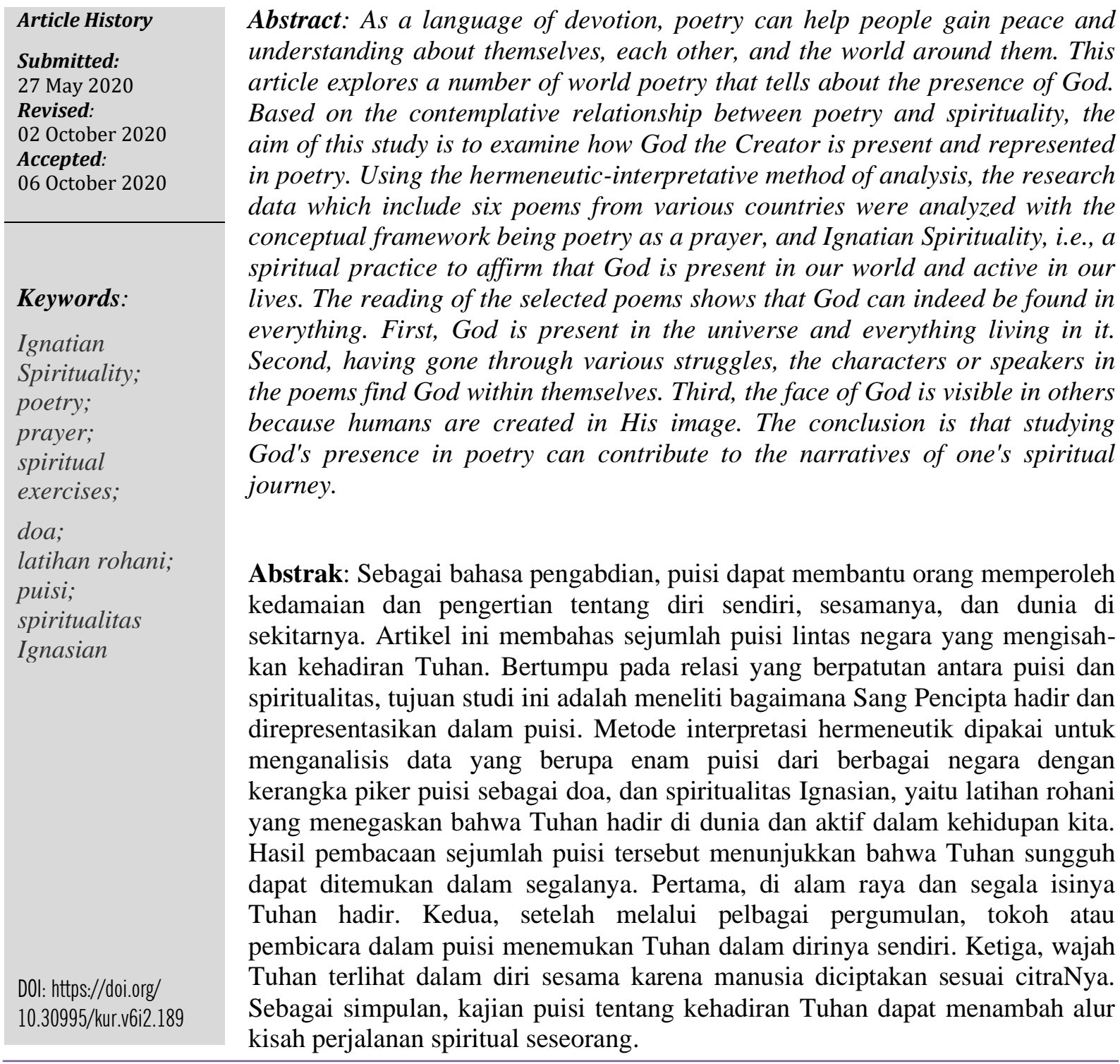

\section{Pendahuluan}

Puisi-puisi religius dari semua tradisi dan ajaran agama pada umumnya berbicara tentang iman, yakni membawa pembaca lebih dekat kepada Yang Ilahi, selain keindahan, moralitas, 
dan perilaku yang luhur. ${ }^{1}$ Syair-syair indah dalam Kitab Kidung Agung, menurut Auwers, misalnya, menggambarkan kasih Allah yang besar kepada bangsa Israel. Puisi merupakan latihan spiritual yang menciptakan kejelasan dan memperluas eksplorasi terus-menerus ke dalam misteri kehidupan yang paling mendalam. Sikap syukur dan hormat sedalam-dalamnya kepada keagungan Ilahi ditampilkan oleh penyair dari berbagai agama dan aliran kepercayaan sepanjang waktu. Dalam Poetry as Spiritual Practice, Robert McDowell mengatakan bahwa setiap orang beragama apapun bahkan seorang atheis selalu mencari spiritualitas dalam kesehariannya baik disadari atau tidak. ${ }^{2}$ Kajian tentang hubungan antara puisi dan spiritualitas telah melimpah, terutama tentang penyair-penyair besar dengan latar belakang budaya dan agama-agama besar di dunia: Jalāl ad-Dīn Muhammad Rūmī penyair Sufi dari Persia, penyair China T'ao Ch'ien yang berisikan ajaran-ajaran Budha, Lao-tzu dan falsafah Taoisme dalam puisi-puisinya, Vyasa dengan puisi epik Mahabharata, puisi Kristiani dalam Perjanjian Baru, dan sebagainya.

Tak pelak lagi, hubungan antara sastra dan iman Kristen dapat disimak dalam puisipuisi dari pelbagai penjuru dunia. Telah banyak pula studi tentang sinergi antara puisi dan spiritualitas Kristiani dari karya klasik sampai kontemporer. Clutterbuck dalam Encounters with God in Medieval and Early Modern English Poetry, misalnya, menyajikan analisis linguistik atas sejumlah puisi terkenal dalam sastra Inggris. ${ }^{3}$ Salah satu temuan Clutterbuck adalah terjadinya dialog antara manusia dengan Tuhan dalam puisi-puisi religius tersebut yang sejauh ini kerap diabaikan oleh para ahli tata bahasa dan sastra. Puisi-puisi religius yang dibahas oleh Clutterbuck antara lain "Piers Plowman" karya William Langland, Divine Poems kumpulan puisi dari John Donne, dan karya terkenal John Milton "Paradise Lost". ${ }^{4}$ Soneta Suci karya John Donne (1572-1631) bentuknya sederhana dan membahas tema-tema religius tentang kefanaan, penghakiman Ilahi, cinta Ilahi, dan penebusan dosa. Semua itu dikemas dalam syair-syair yang indah namun menyiratkan kecemasan yang sangat pribadi sifatnya. Sementara itu, karya Milton berbicara tentang kejatuhan manusia di Taman Firdaus. Menurut McMahon, Yesus Sang Putra sama sekali tidak digambarkan sebagai seorang pahlawan yang menang, tetapi masih tetap diakui sebagai penyelamat umat manusia yang jatuh dalam dosa. ${ }^{5}$ Kekalahan Yesus bukan karena cacat-Nya, tetapi karena keinginan-Nya untuk mati bagi manusia. Sesungguhnya, di sinilah kekuatan heroik terbesar Yesus. Yang dapat disimpulkan di sini adalah bahwa puisi menawarkan perspektif yang barangkali berbeda dengan penjelasan ilmiah yang Teologis dan filsafati, akan tetapi tidak dapat dipungkiri manfaatnya untuk pendidikan iman Kristiani.

\footnotetext{
${ }^{1}$ Jean-Marie Auwers, 'The Song of Songs and the Eros of God. A Study in Biblical Intertextuality', Revue Théologique de Louvain, 2012.

${ }^{2}$ Robert McDowell, Poetry as Spiritual Practice (New York: Free Press, 2008).

${ }^{3}$ Lawrence Besserman and Charlotte Clutterbuck, 'Encounters with God in Medieval and Early Modern English Poetry', The Sixteenth Century Journal, 2007 <https://doi.org/10.2307/20478376>.

${ }^{4}$ Charlotte Clutterbuck, 'Finding the Balance in the C-Revision of Piers Plowman: Faith-Grace-Mercy versus Hope-Works-Justice', in Encounters with God in Medieval and Early Modern English Poetry, 2018 <https://doi.org/10.4324/9781315256535-4>.

${ }^{5}$ Michael P. McMahon, 'Jesus Christ as The Modern Hero in John Milton's Paradise Lost', Inquiries Journal/Student Pulse, 2 (2010).
} 
Karya sastra religi Kristen monumental lainnya adalah The Temple yang terbit pada 1633. Kumpulan puisi karya George Herbert ini menggambarkan hubungan timbal balik antara manusia dan Tuhan. Melalui The Temple Herbert menunjukkan bahwa manusia adalah rumah bagi kemuliaan Allah; dan hati manusia adalah tempat Tuhan bersemayam. ${ }^{6}$ Herbert merupakan salah satu penyair klasik yang karya-karyanya kerap dikaji baik secara sastrawi maupun dalam dialog antara seni dan teologi khususnya iman Kristiani. Imam Gereja Anglikan di Katedral Salisbury di Inggris abad ketujuh belas ini dikenal sebagai penyair religius paling terkenal dalam sastra Inggris antara lain karena kesederhanaan pemilihan diksi dan pemakaian metafora dalam puisi-puisinya. ${ }^{7}$

Pengaruh George Herbert terlihat pada penyair kontemporer dan juga pastor Anglikan Malcolm Guite yang menerbitkan soneta sesuai kalender liturgi. ${ }^{8}$ Kumpulan puisi terbaru Guite, After Prayer, dimulai dengan serangkaian soneta untuk menanggapi puisi terkenal Herbert lainnya yaitu "Doa". Dalam sebuah wawancara, pastor, penyair, dan pengajar di Girton College, University of Cambridge ini mengakui pengaruh George Herbert yang amat besar terhadap kreativitasnya. Terinspirasi oleh Herbert, puisi-puisi Guite menjadi saksi bagaimana seni dan iman bekerja bersama dalam kehidupannya. ${ }^{9}$ Puisi-puisi Guite memberikan wawasan dan keterhubungan dengan kisah-kisah Alkitab dengan cara baru. Ia juga menulis sejumlah kajian ilmiah tentang puisi dan Teologi semisal Faith, Hope and Poetry: Theology and the Poetic Imagination ${ }^{10}$ yang telah mendapatkan banyak pengakuan serta apresiasi. ${ }^{11}$ Guite juga mengkaji karya-karya C.S. Lewis yang menghantarkan penulis Inggris itu ke pertobatannya dan bahkan menjadi seorang teolog awam.

Seperti Guite dan penulis-penulis klasik tadi, penulis kontemporer lainnya, Shemaiah Gonzalez, berpendapat bahwa puisi merupakan salah satu cara menemukan Tuhan. Karyakarya kontemplatif dari zaman ke zaman ini berbicara tentang pengalaman (unik) tentang perjumpaan dengan Tuhan yang dibungkus dengan realitas sastrawi sehingga pengalaman

\footnotetext{
${ }^{6}$ Nicole M. Hwang, 'In the House of God: Divine Authority and the Collectivity of Spiritual Experience in George Herbert's The Temple and Ralph Vaughan Williams' Five Mystical Songs', 2018.

${ }^{7}$ Kelley S. Kent, 'The Typology of Sacrifice in George Herbert's The Temple', Inquiries Journal/Student Pulse, 5.07 (2013).

${ }^{8}$ Malcolm Guite, 'More than "a Moment's Monument”, Book 2.0, 2017

<https://doi.org/10.1386/btwo.6.1-2.81_1>; Malcolm Guite, 'The Word and the Words';, in The King James Version at 400, 2017 <https://doi.org/10.2307/j.ctt5hjgtt.28>; Malcolm Guite, Faith, Hope and Poetry, Faith, Hope and Poetry, $2020<$ https://doi.org/10.4324/9781315255491>.

9 Joelle Kidd, "'Something Understood”: English Poet Malcolm Guite on Prayer, Priesthood and Sonnets', Anglican Journal, February 6, $2020<$ https://www.anglicanjournal.com/something-understoodenglish-poet-malcolm-guite-on-prayer-priesthood-and-sonnets/>.

${ }^{10}$ Guite, Faith, Hope Poet. Lihat Malcolm Guite, "CS Lewis: Apologetics and the poetic imagination." Theology 116.6 (2013): 418-426. https://doi.org/10.1177\%2F0040571X13501264; Malcolm Guite, 'C.S. Lewis: On Both Sides of the Wardrobe', Religious Studies Review, $2011<\mathrm{https} / /$ doi.org/10.1111/j.17480922.2011.01502.x>.

${ }^{11}$ K. Neumann, 'Faith, Hope and Poetry: Theology and the Poetic Imagination. By Malcolm Guite.', Literature and Theology, 2012 <https://doi.org/10.1093/litthe/frs003>; G. Richardson, 'MALCOLM GUITE, Faith, Hope and Poetry: Theology and the Poetic Imagination.', Notes and Queries, 2013 <https://doi.org/10.1093/notesj/gjs243>; Charles C. Twombly, 'Book Review: Faith, Hope and Poetry: Theology and the Poetic Imagination', Christianity \& Literature, 2013 <https://doi.org/10.1177/014833311306200212>.
} 
yang nampaknya bersifat pribadi itu bisa dirasakan juga oleh orang lain. ${ }^{12}$ Gonzalez berjumpa dengan Tuhan dalam kesehariannya lewat keempat hal berikut ini. Pertama, touchstone atau batu sentuh, yaitu benda-benda apa saja yang mengingatkan kita bahwa Allah ada di sini, bersama kita, dengan cara yang sangat pribadi, misalnya melalui kupu-kupu, bunga, daun, pohon, dan sebagainya. Tuhan juga hadir di tempat yang tersembunyi yang kedua yaitu suara. Gonzalez telah menulis sejumlah artikel tentang keheningan tetapi akhirnya menyadari bahwa Tuhan tidak hanya ditemukan dalam keheningan, tetapi dalam suara-suara berisik yang tertinggal, bahkan keramaian. Tempat ketiga Tuhan ditemukan adalah di rumah, ketika kita sedang mengerjakan pekerjaan sehari-hari. Dalam hal ini Gonzalez meneladan St. Theresia dari Lisieux yang mengatakan bahwa kehadiran Tuhan dirasakan paling dekat bukan pada saat berdoa, tetapi di tengah-tengah ia melakukan pekerjaan rumah tangga. ${ }^{13}$ Gonzalez juga belajar dari ibu mertuanya yang membesarkan enam anak tetapi senandung mazmur dan lagulagu pujian selalu terdengar dari mulutnya saat ia bekerja. Tugas sekecil apa pun bisa bernilai inkarnasional dan menjadi cara untuk hidup dan menghirup kasih Tuhan.

Dengan demikian, puisi-puisi religius di atas menunjukkan bahwa Tuhan dapat ditemukan di ketiga tempat seperti alam, diri sendiri, dan orang lain. Menurut McDowell, melalui puisi, orang memperoleh kedamaian dan pengertian tentang diri sendiri, sesamanya, dan dunia di sekitarnya. ${ }^{14}$ McDowell mengajak kita menjadikan puisi sebagai bagian penting dari ritual, aspirasi, dan niat sehari-hari dalam upaya pencarian makna, pertumbuhan, dan kedamaian yang lebih besar dalam hidup. Terinspirasi antara lain oleh McDowell, meditasi setiap hari, membaca Mazmur, membuat lukisan mandala, dan menulis tanggapan puitis atas ayat yang dibaca juga dilakukan oleh Owens. ${ }^{15}$ Praktik spiritual yang dilakukan Owens ini bertumpu pada fondasi terapi seni ekspresif yang mengintegrasikan seni dalam terapi dan dapat dimodifikasi untuk beragam teks puitis asalkan cocok dengan wawasan, pertumbuhan pribadi, dan refleksi diri.

Pelbagai aktivitas untuk membuka diri kepada Tuhan dan membiarkan-Nya masuk ke diri kita seutuhnya disebut latihan rohani yang dijadikan sebagai kerangka pikir dalam analisis puisi-puisi di sini. Latihan Rohani sebagaimana dipahami dalam Spiritualitas Ignasian secara tidak langsung telah dilakukan oleh para penyair yang mendefinisikan puisi sebagai praktik spiritual. Menjadi kontemplatif dalam tindakan berarti bahwa kehidupan aktif kita memberi umpan bagi kehidupan kontemplatif; dan kehidupan kontemplatif ini memberi informasi atau menuntun kehidupan aktif kita. Di situlah Tuhan hadir. Aktivitas itu bisa berupa meditasi, merapal doa, membuat catatan harian, menulis puisi, menciptakan karya seni, bermain musik, bahkan berjalan-jalan menikmati alam asalkan bertujuan satu, yaitu membiarkan Tuhan berbicara dan mendengarkan apa yang disabdakan-Nya. ${ }^{16}$

\footnotetext{
${ }^{12}$ Shemaiah Gonzalez, 'Four Hidden Places I’ve Found Godcom', Ignatian Spirituality. Com, 15 January $2020<$ https://www.ignatianspirituality.com/four-hidden-places-ive-foundgod/?utm_source=emagislist\&utm_medium=email\&utm_content=202001\&utm_campaign=emagis $>$.Gonzalez.

${ }^{13}$ Joann Wolski Conn, 'Therese of Lisieux: Far From Spiritual Childhood', Spiritus: A Journal of Christian Spirituality, 2006 <https://doi.org/10.1353/scs.2006.0029>.

${ }^{14} \mathrm{McD}$ Dowell.

${ }^{15}$ Donna C. Owens, 'Meditations on the Psalms in Words and Images: An Arts-Integrated Spiritual Practice', Journal of Poetry Therapy, 2017 <https://doi.org/10.1080/08893675.2017.1351708>.

${ }^{16}$ An Ignatian Spirituality Reader, ed. by George W. Traub (Chicago: Loyola Press, 2008).
} 
Berangkat dari relasi yang berpatutan antara puisi dan spiritualitas di atas, artikel ini bertujuan untuk melihat bagaimana Sang Pencipta hadir dan diimajinasikan di dalam puisi. Masalah yang akan dikaji dirumuskan demikian: Mengapa dan bagaimana puisi-puisi yang dibahas dapat membantu kita mengalami kehadiran Tuhan?

\section{Metode Penelitian}

Penelitian kualitatif-interpretatif ini menggunakan metode penelitian pustaka yang lazim berlaku dalam kajian teks-teks sastra ${ }^{17}$, maupun agama. ${ }^{18}$ Data dalam penelitian ini adalah karya-karya puisi yang ditulis oleh penyair dari pelbagai negara. Puisi-puisi yang dikaji dibatasi dengan penggunaan bahasa Indonesia atau bahasa Inggris saja, baik asli maupun terjemahan. Mengingat banyaknya puisi yang ada, dipilih sejumlah puisi yang sudah terbit baik cetak maupun daring. Dalam hal ini puisi dalam bentuk catatan harian, bagian dari buku (prolog, epilog, dedikasi, dsb.), blog, dan berbagai media tidak dianggap sebagai data dan hanya disinggung sekilas dalam pembahasan apabila relevan. Berikut judul puisi, pengarang, dan asal negaranya: (1) "I Never Saw a Moor" (Emily Dickinson, Amerika), (2) "Nothing Is Far" (Robert Francis, Amerika), (3) "Misal" (Joko Pinurbo, Indonesia), (4) "Who Hides" (Derrick Mendis, Sri Lanka), (5) "Kolam" (Bakdi Soemanto, Indonesia), dan (6) "Paskah di Kentucky Fried Chicken" (Subagio Sastrowardoyo, Indonesia). Data lain berupa penggalan puisi atau kutipan dari beberapa penulis klasik dunia seperti William Blake, John Henry Newman, Fyodor Dostoevsky, dan sebagainya, dipergunakan dalam pembahasan sebagai tambahan penjelasan. Akan halnya sumber data sekunder, penelitian ini menggunakan artikel jurnal, surat kabar, majalah, dan buku-buku yang membahas mengenai topik terkait baik dalam bentuk daring maupun cetak. Data yang diambil berkenaan dengan pengarang, karya dan dunianya yang sesuai dengan tema perjumpaan dengan Tuhan.

Penelitian ini memakai sembilan langkah penelitian perpustakaan yang digagas oleh Mary George, yakni mengubah imajinasi menjadi wawasan. ${ }^{19}$ Pertama, peneliti memilih topik. Kedua, topik diubah menjadi imajinasi. Memperjelas pertanyaan penelitian adalah langkah ketiga. Langkah keempat adalah menyusun strategi penelitian, dilanjutkan dengan langkah kelima, yaitu mencari referensi dari berbagai basis data. Dalam penilitian ini dilakukan klasifikasi data menurut pengarang berdasarkan latar belakang negara dan budaya, tema, dan gaya penulisan. Mencocokkan sumber data dengan pertanyaan penelitian merupakan langkah ketujuh. Terkelompokkan dua buah puisi tentang Tuhan dalam alam semesta, tiga puisi tentang Tuhan dalam diri aku lirik, dan sebuah puisi tentang Tuhan dalam diri sesama. Kemudian, langkah keenam adalah mengidentifikasi sumber data. Langkah kedelapan adalah mengeksplorasi wawasan berdasarkan refleksi. Langkah kesembilan atau terakhir adalah merumuskan pertanyaan penelitian berdasarkan wawasan tersebut.

${ }^{17}$ Mary W. George, The Elements of Library Research: What Every Student Needs to Know, The Elements of Library Research: What Every Student Needs to Know, 2008.

${ }^{18}$ Sonny Eli Zaluchu, 'Strategi Penelitian Kualitatif Dan Kuantitatif Di Dalam Penelitian Agama', Evangelikal: Jurnal Teologi Injili Dan Pembinaan Warga Jemaat, 2020 <https://doi.org/10.46445/ejti.v4i1.167>.

${ }^{19}$ George W. Traub. 
Puisi sebagai karya imaginatif bersifat multitafisir. Oleh karena itu, analisis konten yang digunakan dalam penelitian ini adalah interpretasi hermeneutik. ${ }^{20}$ Menurut Zaluchu, desain penelitian hermeneutika interpretatif tidak menerima penafsiran mutlak karena setiap interpretasi ditempatkan pada konteks dan tujuan tertentu. ${ }^{21}$ Setelah data berupa keenam puisi diklasifikasikan, data tersebut ditafsirkan melalui tahapan berikut: membentuk pola hermeneutik berupa pendefinisian kategori sastra (puisi religius); menangkap gagasan utama penyair (di mana saja Tuhan bersemayam); melihat teks dalam konteks (mengapa puisi ditulis sedemikian); dan memperhatikan gaya bahasanya (metafora, simbol, ironi, dan sebagainya).

\section{Pembahasan}

\section{Menemukan Tuhan di Alam Raya}

Alam raya dan seisinya merupakan tempat favorit para penulis ketika mensyairkan keberadaan Tuhan. Sang Pencipta yang tak kasat mata itu singgah di debur ombak, pohon dan rerumputan yang berdesir, kicauan burung, dan bebatuan. Penyair perempuan asal Amerika Emily Dickinson lewat puisi singkat "I Never Saw a Moor" menyampaikan pesan yang kuat tentang iman, yakni: Tuhan ada meskipun tak sekalipun ia melihat atau berbicara kepada Dia. Seperti hampir semua puisi Dickinson lainnya, puisi dua stanza yang ditulis pada 1924 ini memakai tanda baca unik yaitu tanda pisah di akhir baris dan hanya satu tanda titik saja di stanza pertama. Banyak spekulasi tentang penggunaan tanda baca dan cara penulisan unik lainnya seperti dipakainya nomor bukan judul untuk puisi-puisi Dickinson. Perlu diketahui bahwa karyanya diterbitkan setelah Dickinson meninggal sehinga editor yang berbeda-beda mempunyai kebebasan menampilkan puisi-puisi itu.

Menurut Fagan, misalnya, pemakaian tanda pisah menegaskan gaya penyair ketika hendak menyampaikan ketidakmampuannya menuangkan seluruh luapan emosinya ke dalam kata-kata. ${ }^{22}$ Pada puisi "I Never Saw a Moor", setelah mengaku tidak pernah ke padang rumput untuk tahu seperti apa itu heather (semacam bunga lavender) dan juga ombak yang bergulung-gulung tanpa pergi ke laut, Dickinson seakan terbata ketika meyakinkan bahwa surga itu ada. Sama seperti kebanyakan masyarakat di New England yang hidup di zaman itu, Dickinson secara statistik memeluk agama Protestan yang beraliran Calvinis. Sebagai seorang perempuan lajang yang memutuskan diri menjadi pertapa dan tidak pernah ke gereja, sejumlah kajian menyebutkan bahwa nafas iman dihembuskan dalam karya-karyanya. ${ }^{23}$ Puisi-

${ }^{20}$ Sonny Eli Zaluchu, 'Pola Hermenetik Sastra Hikmat Orang Ibrani', Evangelikal: Jurnal Teologi Injili Dan Pembinaan Warga Jemaat, 2019 <https://doi.org/10.46445/ejti.v3i1.123>.

${ }^{21}$ Zaluchu, 'Strategi Penelitian Kualitatif Dan Kuantitatif Di Dalam Penelitian Agama'; Zaluchu, 'Pola Hermenetik Sastra Hikmat Orang Ibrani'.

${ }^{22}$ Deirdre Fagan, 'Emily Dickinson's Unutterable Word', The Emily Dickinson Journal 14.2 (2005): 70752005 <https://doi.org/10.1353/edj.2006.0006>.

${ }^{23}$ Lihat antara lain Roxanne Harde, “Some-Are like My Own-”: Emily Dickinson's Christology of Embodiment', Christianity \& Literature 53.3 (2004): 315-336. <https://doi.org/10.1177/014833310405300302>; Magdalena Zapedowska, 'Wrestling with Silence: Emily Dickinson's Calvinist God' American Transcendental Quarterly 20.1 (2006): 379. 
puisi Dickinson menggambarkan pergumulannya dengan konsep tentang Tuhan melalui pelbagai peristiwa dan penderitaan yang disaksikannya pada masa itu. ${ }^{24}$

Kehadiran Tuhan di sekeliling kita juga jelas terlihat dalam "Nothing Is Far" karya Robert Francis (1901-1987) penyair asal Upland, Pennsylvania yang mendapat pengaruh besar dari penyair Amerika sezamannya yang lebih terkenal yaitu Robert Frost. Ditulis dengan gaya sajak bebas ala Frost, puisi ini bercerita tentang kehadiran Tuhan yang nama-Nya tidak pernah terdengar melaui kicau burung atau desiran angin akan tetapi sungguh dialami oleh si penyair. Bahwa Tuhan hadir di mana-mana terlihat jelas dalam bait ke-3: "Tidak ada yang jauh yang pernah dekat /Tidak ada yang tersembunyi yang pernah terlihat /Tidak ada Tuhan yang tidak ada di sini”. Puisi ini diakhiri dengan: "Inilah burung, pohon, batu /Di sini di bawah sinar matahari ku duduk sendiri /Antara yang kukenal dan yang tak kukenal.”

Kehadiran Tuhan dalam semesta dan segala isinya ini sesuai dengan Latihan Rohani dalam Spiritualitas Ignasian, seperti dijelaskan dalam "Azas dan Dasar" bahwa Tuhan menciptakan manusia dan terus hadir dalam diri kita dengan penuh cinta. Untuk menyambut kasih Tuhan itu, tidak ada yang lebih mulia selain memuji, menghormati dan mengabdi Tuhan sendiri. ${ }^{25}$ Benda di sekitar kita menjadi batu sentuh, untuk meminjam istilah Gonzalez, ${ }^{26}$ yang menyadarkan kita tentang kehadiran Tuhan dan kasih-Nya yang begitu besar di setiap saat dan waktu. Salah satu ajaran pokok dalam Spiritualitas Ignasian adalah mengarahkan hidup seseorang sebagai ciptaan agar sesuai dengan maksud dan kehendak Tuhan sendiri dan dengan itu ia memuji dan memuliakan nama-Nya (Ad Maiorem Dei Gloriam). Baik Dickinson maupun Francis tidak pernah bertemu satu sama lain. Mereka melihat batu sentuh yang berbeda di tempat dan waktu yang berbeda-beda pula, tetapi hati kedua penyair ini sama-sama bergetar ketika melihat aneka ciptaan (angin, ombak, burung, batu, bunga, rumput, dan lain-lain) dan pada saat itulah pribadi-pribadi itu merasakan bahwa Sang Pencipta, sungguh, telah, dan selalu hadir.

Refleksi Teologis puisi-puisi di atas gayut dengan ayat-ayat dalam Alkitab tentang keberadaan Tuhan di alam semesta. Pemazmur berkata: "Ke mana aku dapat pergi menjauhi roh-Mu, ke mana aku dapat lari dari hadapan-Mu? Jika aku mendaki ke langit, Engkau di sana; jika aku menaruh tempat tidurku di dunia orang mati, di situ pun Engkau. Jika aku terbang dengan sayap fajar, dan membuat kediaman di ujung laut, juga di sana tangan-Mu akan menuntun aku, dan tangan kanan-Mu memegang aku.” (Mzm. 139: 7-10).

\section{Tuhan Bersemayam di Batin Manusia}

Bahwa akhirnya Tuhan ditemukan di semua ciptaan termasuk di hati manusia juga terbukti lewat puisi tanah air yakni "Misal" karya Joko Pinurbo. Dalam puisi ini dikisahkan bahwa Tuhan bertanya "Misal Aku datang ke rumahmu" kepada seseorang yang sedang khusuk berdoa. Lanjut Tuhan: “Akankah kau keluar dari doamu dan membukakan pintu untukKu?"27

\footnotetext{
${ }^{24}$ Magdalena Zapedowska, ‘A Lesson in Grammar: Dickinson's "Grasped by God"; and "Drowning Is Not so Pitiful"', The Emily Dickinson Journal, 2006 <https://doi.org/10.1353/edj.2006.0026>.

${ }^{25}$ Ignatius Loyola, Latihan Rohani (Terjemahan J. Darminta SJ) (Yogyakarta: Penerbit-Percetakan Kanisius, 1993).

${ }^{26}$ Gonzalez.

${ }^{27}$ Joko Pinurbo, “"Misal”, in Buku Latihan Tidur: Kumpulan Puisi Joko Pinurbo (Jakarta: GPK, 2017), p. 42 .
} 
Terdapat makna tertentu di balik judul puisi Pinurbo yang ditulis pada 2016 ini. Judul "Misal" selain berarti "umpama, seandainya", sekilas terdengar seperti "misa" atau "missal" dalam bahasa Inggris yaitu sebuah buku yang berisi teks-teks yang digunakan dalam Kebaktian atau Perayaan Ekaristi di Gereja Katolik sepanjang tahun.

Penulis yang terkenal antara lain dengan puisi cekaknya "Doa Malam" yang berbunyi "Tuhan yang merdu, terimalah kicau burung dalam kepalaku" ini mengolah Kitab Suci yang baginya merupakan sumber inspirasi yang tak pernah mengering. Seperti diakuinya sendiri, ayat favoritnya adalah 1 Tesalonika 5:18 yang berbunyi "Mengucap syukurlah dalam segala hal, sebab itulah yang dikehendaki Allah di dalam Kristus Yesus bagi kamu."28 Spiritualitas kepenyairan Joko Pinurbo didapat dari buku Latihan Rohani 23. Tanpa bait-bait yang menggurui, pembaca puisinya cukup cerdas untuk menangkap dan menciptakan makna atas pesan moral di dalamnya tentang peristiwa-peristiwa, baik yang sifatnya pribadi maupun sosial, seputar hubungan Tuhan dengan manusia dan relasi antarmanusia. ${ }^{29}$ Sebagai catatan, puisi Pinurbo yang lain berjudul "Pemeluk Agama" memberikan amanat bahwa agama adalah sarana bukan tujuan karena kerinduan dan hubungan yang intim dan intens dengan Allah sendiri lebih penting ketimbang ritual dan formalitas beragama. Puisi ini membandingkan orang yang mengaku pemeluk teguh agama dan Teguh si tukang bakso di hadapan Tuhan. Bandingkan dengan doa seorang Farisi dan seorang pemungut cukai (Luk. 18:10-14).

Puisi Pinurbo melihat keraguan umat beragama ketika menjalankan ibadahnya. Banyak dari kita terperangkap dalam pemikiran bahwa satu-satunya tempat untuk menemukan Tuhan adalah di gereja, masjid, dan tempat peribadatan lainnya. Ketika kita tidak berharap menemukan Tuhan di tempat lain kecuali di bermacam bangunan suci atau yang disakralkan tadi, mungkin kita akan kehilangan peluang besar untuk menerima penghiburan dan penyembuhan, serta pertumbuhan rohani dari Tuhan sendiri. Padahal, Tuhan begitu dekat. Kutipan emas "Tuhan hanya sejauh doa" terefleksikan secara kritis dalam puisi "Misal".

Dapat dikatakan bahwa pembicara atau aku lirik pada "Misal" menemukan Tuhan melalui diskresi. Diskresi merupakan inti dari Spiritualitas Ignasian. Melalui diskresi kita menyentuh bagian terdalam diri kita, ruang di mana Tuhan berbicara kepada kita. Seperti tertulis dalam Amsal 2:10-11: "Karena hikmat akan masuk ke dalam hatimu dan pengetahuan akan menyenangkan jiwamu; kebijaksanaan akan memelihara engkau, kepandaian akan menjaga engkau." Diskresi bukan hanya diperlukan untuk menyelesaikan masalah besar, tetapi alat perjuangan untuk mengikuti Tuhan dengan semakin baik dari waktu ke waktu. Melalui puisi ini terbaca kisah seseorang yang menemukan Tuhan melalui komunikasi yang sangat intim dan pribadi.

Selanjutnya, "Aku mencari wajahmu dengan hati yang rindu”, tulis Derrick Mendis, seorang pastor asal Sri Lanka, "Tolong jangan sembunyi; Jadilah pemanduku, akan kupatuhi". ${ }^{30}$ Atas permohonan ini, puisi berjudul "Who Hides" ini berlanjut demikian: "Tuhan menjawab- /Melalui kehidupan /Aku membimbingmu hari demi hari /Menggiringmu dengan lembut, saat Engkau tersesat / Denganmu, di sampingmu, terus-menerus /Kaulah

\footnotetext{
${ }^{28}$ Joko Pinurbo, 'Kitab Suci: Inspirasi Menulis Puisi (Bagian 2)', Rohani, 02.65 (2018), p. 41.

${ }^{29}$ Pinurbo, 'Kitab Suci: Inspirasi Menulis Puisi (Bagian 2)', p. 42.

${ }^{30}$ Derrick Mendis, 'Who Hides', in Musings \& Meanderings (Dehiwala: Carl Fernando, 2008), p. 38.
} 
kasihku, yang bersembunyi dariKu". Dalam "Who Hides", Derrick Mendis membuktikan bahwa Tuhan tidak pernah bersembunyi. Melalui puisi ini, penyair membuktikan bahwa Tuhan tidak perlu dicari karena diri kita sendirilah yang selama ini bersembunyi atau menghindar dari Tuhan. Bagi seorang Yesuit seperti Mendis, Latihan Rohani tidak bisa tidak telah menjadi nafas kehidupannya. Pertemuan dengan Allah yang pengasih merupakan inti dari misi St. Ignasius de Loyola dan rekan-rekan serikatnya. Berdasarkan pada keyakinan bahwa Allah aktif di dunia nyata, jalan spiritual yang ditetapkan oleh pendiri Serikat Yesus ini membantu kita membedakan kehadiran Tuhan, menemukan Tuhan dalam segala hal, dan menjangkau dunia yang beragam, penuh rahmat namun tidak sempurna. Spiritualitas ini dibawa ke dalam konteks manusia yang lebih luas dalam rangka mengupayakan keadilan sosial, perdamaian, dan dialog.

Pertanyaan mengapa manusia sembunyi dari Tuhan seakan dijawab oleh puisi Bakdi Soemanto berjudul "Kolam". Puisi ini merupakan monolog seseorang yang mencoba mengingat kembali nasihat yang diberikan oleh kekasihnya untuk tidak mengusik air kolam yang tenang dan bening saat mereka berduaan. Pantulan langit, daun-daun, dan debu yang diterbangkan angin jatuh di permukaan kolam itu. Nasihat itu berlanjut demikian: "Jangan kau usik, katamu, /hatimu yang tenang dan bening itu. /Lihatlah, katamu, /wajah Tuhan terpantul/ juga gema sabda-Nya menggetarkan permukaan."31 Penyair menyambut nasihat itu sambil bedesah, "Ah, malah dosa-dosa kita, /khianat dan dendam kita, /menyayat wajah-Nya". Puisi ini seirama dengan Mazmur 139:2, yaitu "Engkau tahu kapan aku duduk dan kapan aku bangun, Engkau memahami maksud-maksudku dari kejauhan dan Engkau juga mengetahui akan dudukku dan akan bangkitku berdiri; dari jauh juga Engkau mengetahui akan segala kepikiranku." Meskipun puisi ini multi-interpretasi, tertangkap adanya keraguan dan penyesalan di dalamnya. Tuhan sungguh nyata dirasakan kehadiran-Nya dalam batin salah satu tokoh ketika ia menyadari perbuatan-perbuatan di masa lalu yang mendukakan Tuhan.

Dari sini dapat disimpulkan sementara bahwa puisi terbukti gayut dengan kehidupan spiritual. Puisi bisa menjadi latihan spiritual atau cara hidup. Kehidupan spiritual berkaitan dengan upaya mengatasi egoisme, kesombongan, purbasangka, dan sebagainya, termasuk rasa gamang untuk bertemu dengan Tuhan. Temuan ini bersetuju dengan pendapat Robert McDowell di atas bahwa lewat puisi diperoleh kedamaian dan pengertian tentang diri sendiri, orang lain, dan dunia yang lebih luas. ${ }^{32}$ Puisi adalah latihan rohani untuk menemukan makna, kedewasaan, dan damai sejahtera di lubuk hati sang penyair.

\section{Tuhan dalam Diri Sesama}

Tidak ada puisi yang lebih gamblang tentang kehadiran Tuhan dalam diri sesama dibandingkan dengan Injil Matius 25:35-40. Kelima ayat penting ini berisi tentang ajaran cinta kasih untuk merawat orang sakit, menyambangi pesakitan di dalam penjara, dan memberi tumpangan kepada orang asing. Sebelumnya, telah disebutkan juga dalam Matius 18: 20, "Di mana dua atau tiga orang berkumpul dalam Nama-Ku, di situ Aku ada di tengah-tengah mereka." Yesus mengajarkan kita untuk mencintai sesama seperti mencintai diri sendiri.

${ }^{31}$ Bakdi Soemanto, 'Kolam', in Kata: Antologi Puisi 1976 - 2006 Bakdi Soemanto (Yogyakarta: Penerbit Bentang, 2007), p. 121.

${ }^{32}$ McDowell. 
Inilah praktik nyata keadilan terhadap sesama manusia sekaligus kesaksian akan kehadiran Tuhan. Ajaran kasih dalam ayat-ayat sakral ini terbaca dalam puisi-puisi yang akan dicermati lebih lanjut di bawah ini.

Tema "menemukan Tuhan dalam diri sesama" kerap kali muncul dalam puisi dari waktu ke waktu. Sebelum membahas puisi yang dipilih dalam kajian ini, berikut selayang pandang beberapa puisi terkenal yang menggambarkan kehadiran Tuhan dalam diri orang lain. Mary Dawson Hughes menggambarkan kehadiran Tuhan lewat sebuah haiku demikian: Jari Tuhan menyentuh hidup Anda ketika Anda berteman. Demikian pula karya penginjil John Henry Newman ini: Kuberusaha mendengar suara Tuhan /Dan memanjat menara paling atas /Tetapi Tuhan menyatakan: "Turunlah lagi - Aku tinggal di antara orang-orang." Contoh lain, "Cintai semua ciptaan Tuhan, baik keseluruhan dan setiap butiran pasir. Cintai setiap daun, setiap sinar cahaya. Cintai binatang, cintai tanaman, cintai segala sesuatu," kata Bapa Zosima dalam The Brothers Karamazov karya Fyodor Dostoevsky. Dengan mencintai setiap hal, Zosima meyakinkan bahwa manusia akan merasakan misteri Allah dalam segalanya; dan begitu manusia memahami hal ini dipahami, tidak sulitlah mencintai seluruh dunia dengan cinta yang serba merangkul dan universal.

Jika kita meyakini bahwa manusia diciptakan menurut gambar Allah, maka cara kita belajar tentang Allah adalah hidup dengan kasih terhadap sesama. Dalam "Azaz dan Dasar" Spiritualitas Ignatian dikatakan bahwa "segala sesuatu yang juga diciptakan Tuhan karena cintaNya, dengan demikian harus digunakan dan dipersembahkan kepadaNya dengan penuh hormat dan cinta, untuk memuliakan Tuhan dan mencintai sesama, dengan bertanggungjawab dan tidak lekat pada ambisi pribadi". ${ }^{33}$ Prinsip ini gayut dengan pesan yang disampaikan oleh seorang pendeta, penulis, dan pengacara Khristi Lauren Adams dalam buku terbarunya Parable of the Brown Girl: The Sacred Lives of Girls of Color. Di antara sejumlah puisi yang dikutip oleh Adams adalah karya William Blake penyair Inggris abad ke-18 yang terkenal "I Sought My God": Ku mencari jiwaku, /Tapi jiwaku tak bisa kulihat. /Kucari Tuhanku, /Tetapi Tuhanku luput dariku. /Kucari saudaraku, /Dan kutemukan ketiganya. ${ }^{34}$ Buku Adams ini berkisah tentang perempuan muda kulit berwarna yang sering diabaikan, tidak dihargai, ataupun didengar pendapatnya dalam masyarakat di Amerika pada umumnya. Seperti halnya Yesus sendiri yang mengajar dengan memakai banyak perumpamaan, Adams menampilkan gadis-gadis kulit berwarna sebagai tokoh utama dalam cerita guna memaknai perjuangan, mimpi, harapan, dan martabat mereka. Dalam diri orang-orang kecil dan terpinggirkan inilah wajah Tuhan terlihat. Dengan mengutip puisi Blake, Adams ingin menunjukkan bahwa Tuhan menciptakan manusia yang berbeda satu dengan yang lain untuk saling mengasihi. Gadis kulit berwarna yang lemah yang biasanya tidak diperhatikan diangkat kisahnya oleh Adams untuk menunjukkan bahwa Allah memakai kelemahan untuk membuktikan kuasaNya seperti yang dikatakan oleh Rasul Paulus kepada jemaatnya di Korintus (1 Korintus 1: 27-29).

Akhirnya, seorang penyair ingat akan Tuhan ketika melihat yang lemah, miskin, dan menderita dalam "Paskah di Kentucky Fried Chicken". Ditulis oleh Subagio Sastrowardoyo

${ }^{33}$ Loyola, p. 3.

${ }^{34}$ Khristi Lauren Adams, Parable of the Brown Girl: The Sacred Lives of Girls of Color. Augsburg Fortress, Publishers, 2020. JSTOR, www.jstor.org/stable/j.ctvp7d4nq. Accessed 21 May 2020. 
penyair generasi baru Indonesia modern sesudah Angkatan 1945, puisi ini berkisah tentang seseorang yang urung menyantap ayam goreng ketika melihat bayi menangis dalam gendongan seorang perempuan kurus yang sedang mengais tong sampah di muka restoran. Katanya lebih lanjut: Coca-cola terasa kesat di tenggorokan /ketika teringat kepada muka-muka ceking /dirubung lalat hijau di gurun pasir. ${ }^{35}$ Kemiskinan dan ketidakadilan yang terjadi di belahan dunia lain juga disorotnya. Lalu, bak Sang Kristus yang rela mengorbankan diri berkatalah ia: Mari potong-potonglah tubuhkku /dan nikmati dagingku - roti yang paling putih /dan darahku - anggur yang paling murni. Penyair yang puisinya berlatar lintas negara ini mengakhiri puisinya demikian: Eli, Eli, lama sabakhtani - Tuhan, Tuhanku /mengapa kami Kau terlantarkan? Meskipun puisi Sastrowardoyo ini ditulis beberapa dasawarsa yang telah silam, kesenjangan antara yang kaya dan yang miskin merupakan realitas dunia yang terus dihadapi hingga saat ini. Karena itu, puisi ini secara tak langsung menggemakan Sabda Tuhan: Aku berkata kepadamu, sesungguhnya segala sesuatu yang tidak kamu lakukan untuk salah seorang dari yang paling hina ini, kamu tidak melakukannya juga untuk Aku (Mat. 25:46). Atas dasar kasih kepada sesama tersebut Tuhan dihadirkan dalam sejumlah puisi dari zaman ke zaman.

\section{Kesimpulan}

Kajian keenam puisi ini menunjukan bahwa karya sastra dapat membantu kita merasakan kehadiran Tuhan terlebih pada saat menghadapi realitas-realitas dalam masyarakat yang tidak begitu menggembirakan seperti sekarang ini. Sastra merupakan endapan permenungan hidup manusia: keberhasilan, kegagalan, cinta, benci, perdamaian, perang, pengampunan, balasdendam-semuanya dikuak secara imajinatif dan kreatif. Karya sastra semisal puisi-puisi yang telah diulas tadi sarat dengan nilai-nilai luhur disamping kekayaan linguistik maupun artistiknya seperti gaya bahasa, metafora, simbolisme, dan sebagainya. Bagi pembaca maupun penulisnya, puisi bermanfaat karena menghasilkan kebijaksanaan, kasih sayang, kepercayaan diri, kesabaran, dan energi untuk menunjukkan kasih yang lebih besar kepada Sang Pencipta dan seluruh ciptaan-Nya. Oleh sebab itu, dari ketiga temuan yang ada tentang kehadiran Tuhan dalam puisi, yakni alam, diri sendiri, dan sesama manusia, dapat disimpulkan bahwa puisi merupakan doa dan latihan rohani yang dapat mengasah kepekaan batin dan keluhuran budi manusia. Konsep puisi sebagai doa dan latihan rohani telah ditunjukkan dalam keenam puisi yang dibahas dari Amerika, Indonesia, Inggris, dan Sri Lanka. Terbukti pula bahwa Spiritualitas Ignasian merupakan spiritualitas sehari-hari yang bisa dihidupi oleh siapapun tanpa batasan bangsa, agama, dan budaya manapun.

Mengingat bahwa puisi-puisi yang dikaji adalah karya sastra dunia yang dalam hal ini umum dipelajari dalam disiplin ilmu Bahasa dan Sastra Inggris dan Indonesia, refleksi teologis atas karya-karya tersebut kiranya bermanfaat bagi pembelajar Kristiani pada khususnya, dan umat beriman pada umumnya. Pada kesempatan mendatang, diperlukan kajian yang lebih mendalam untuk masing-masing penulis yang berasal dari berbagai negara itu guna melihat (1) sejauh mana kreativitas mereka bersumber pada sinergi antara seni dan

${ }^{35}$ Subagio Sastrowardoyo, 'Paskah Di Kentucky Fried Chicken', in Walking Westward in the Morning: Seven Contemporary Indonesian Poets, ed. by John H. McGlynn (Jakarta: The Lontar Foundation, 1990), p. 201. 
iman, serta (2) bagaimana kedua hal ini dikontekstualisasikan dengan kondisi sosial-politik saat karya-karya mereka digulirkan. Kedua topik ini kiranya dapat ditelisik lebih jauh dari aspek spiritual-teologis maupun sastrawi.

\section{Referensi}

ADAMS, KHRISTI LAUREN, 'Front Matter', in Parable of the Brown Girl, 2019 <https://doi.org/10.2307/j.ctvp7d4nq.1>

Auwers, Jean-Marie, 'The Song of Songs and the Eros of God. A Study in Biblical Intertextuality', Revue Théologique de Louvain, 2012

Besserman, Lawrence, and Charlotte Clutterbuck, 'Encounters with God in Medieval and Early Modern English Poetry', The Sixteenth Century Journal, 2007 <https://doi.org/10.2307/20478376>

Clutterbuck, Charlotte, 'Finding the Balance in the C-Revision of Piers Plowman: FaithGrace-Mercy versus Hope-Works-Justice', in Encounters with God in Medieval and Early Modern English Poetry, 2018 <https://doi.org/10.4324/9781315256535-4>

Conn, Joann Wolski, 'Therese of Lisieux: Far From Spiritual Childhood', Spiritus: A Journal of Christian Spirituality, 2006 <https://doi.org/10.1353/scs.2006.0029>

Fagan, Deirdre, 'Emily Dickinson's Unutterable Word', The Emily Dickinson Journal, 2005 <https://doi.org/10.1353/edj.2006.0006>

George, Mary W., The Elements of Library Research: What Every Student Needs to Know, The Elements of Library Research: What Every Student Needs to Know, 2008

George W. Traub, ed., An Ignatian Spirituality Reader (Chicago: Loyola Press, 2008)

Gonzalez, Shemaiah, 'Four Hidden Places I've Found Godcom', Ignatian Spirituality. Com, 15 January $2020<\mathrm{https} / / \mathrm{www}$.ignatianspirituality.com/four-hidden-places-ive-foundgod/?utm_source=emagislist\&utm_medium=email\&utm_content=202001\&utm_campa ign=emagis $>$

Guite, Malcolm, 'C.S. Lewis: On Both Sides of the Wardrobe', Religious Studies Review, 2011 <https://doi.org/10.1111/j.1748-0922.2011.01502.x>

— Faith, Hope and Poetry, Faith, Hope and Poetry, 2020 <https://doi.org/10.4324/9781315255491>

_ , 'More than "a Moment's Monument"”, Book 2.0, 2017 <https://doi.org/10.1386/btwo.6.1-2.81_1>

_ ' 'The Word and the Words':, in The King James Version at 400, 2017 $<$ https://doi.org/10.2307/j.ctt5hjgtt.28>

Harde, Roxanne, "'Some-Are like My Own_-": Emily Dickinson's Christology of Embodiment', Christianity \& Literature, 2004 <https://doi.org/10.1177/014833310405300302>

Hwang, Nicole M., 'In the House of God: Divine Authority and the Collectivity of Spiritual Experience in George Herbert's The Temple and Ralph Vaughan Williams' Five Mystical Songs', 2018

Kent, Kelley S., 'The Typology of Sacrifice in George Herbert's The Temple', Inquiries Journal/Student Pulse, 5.07 (2013)

Kidd, Joelle, "'Something Understood": English Poet Malcolm Guite on Prayer, Priesthood and Sonnets', Anglican Journal <https://www.anglicanjournal.com/somethingunderstood-english-poet-malcolm-guite-on-prayer-priesthood-and-sonnets/>

Loyola, Ignatius, Latihan Rohani (Terjemahan J. Darminta SJ) (Yogyakarta: PenerbitPercetakan Kanisius, 1993)

McDowell, Robert, Poetry as Spiritual Practice (New York: Free Press, 2008)

McMahon, Michael P., 'Jesus Christ as The Modern Hero in John Milton's Paradise Lost', Inquiries Journal/Student Pulse, 2 (2010) 
Mendis, Derrick, "“Who Hides"”, in Musings \& Meanderings (Dehiwala: Carl Fernando, 2008), p. 38

Neumann, K., 'Faith, Hope and Poetry: Theology and the Poetic Imagination. By Malcolm Guite.', Literature and Theology, 2012 <https://doi.org/10.1093/litthe/frs003>

Owens, Donna C., 'Meditations on the Psalms in Words and Images: An Arts-Integrated Spiritual Practice', Journal of Poetry Therapy, 2017 <https://doi.org/10.1080/08893675.2017.1351708>

Pinurbo, Joko, 'Kitab Suci: Inspirasi Menulis Puisi (Bagian 2)', Rohani, 02.65 (2018), 41 , "Misal”", in Buku Latihan Tidur: Kumpulan Puisi Joko Pinurbo (Jakarta: GPK, 2017), p. 42

Richardson, G., 'MALCOLM GUITE, Faith, Hope and Poetry: Theology and the Poetic Imagination.', Notes and Queries, 2013 <https://doi.org/10.1093/notesj/gjs243>

Sastrowardoyo, Subagio, 'Paskah Di Kentucky Fried Chicken', in Walking Westward in the Morning: Seven Contemporary Indonesian Poets, ed. by John H. McGlynn (Jakarta: The Lontar Foundation, 1990), p. 201

Soemanto, Bakdi, “"Kolam”, in Kata: Antologi Puisi 1976 - 2006 Bakdi Soemanto (Yogyakarta: Penerbit Bentang, 2007), p. 121

Twombly, Charles C., 'Book Review: Faith, Hope and Poetry: Theology and the Poetic Imagination', Christianity \& Literature, 2013 <https://doi.org/10.1177/014833311306200212>

Zaluchu, Sonny Eli, 'Pola Hermenetik Sastra Hikmat Orang Ibrani', Evangelikal: Jurnal Teologi Injili Dan Pembinaan Warga Jemaat, 2019 <https://doi.org/10.46445/ejti.v3i1.123> -, 'Strategi Penelitian Kualitatif Dan Kuantitatif Di Dalam Penelitian Agama', Evangelikal: Jurnal Teologi Injili Dan Pembinaan Warga Jemaat, 2020 <https://doi.org/10.46445/ejti.v4i1.167>

Zapedowska, Magdalena, 'A Lesson in Grammar: Dickinson's \&quot;Grasped by God\&quot; and \&quot;Drowning Is Not so Pitiful\&quot;', The Emily Dickinson Journal, 2006 <https://doi.org/10.1353/edj.2006.0026> , 'Wrestling with Silence: Emily Dickinson's Calvinist God', ATQ, 2006 